\title{
Comparative analysis of the anterior and posterior length and deflection angle of the cranial base, in individuals with facial Pattern I, II and III
}

\author{
Guilherme Thiesen¹, Guilherme Pletsch², Michella Dinah Zastrow³ ${ }^{3}$ Caio Vinicius Martins do Valle ${ }^{4}$ \\ Karyna Martins do Valle-Corotti ${ }^{5}$, Mayara Paim Patel ${ }^{6}$, Paulo Cesar Rodrigues Conti ${ }^{7}$
}

Objective: This study evaluated the variations in the anterior cranial base $(\mathrm{S}-\mathrm{N})$, posterior cranial base $(\mathrm{S}-\mathrm{Ba})$ and deflection of the cranial base (SNBa) among three different facial patterns (Pattern I, II and III). Method: A sample of 60 lateral cephalometric radiographs of Brazilian Caucasian patients, both genders, between 8 and 17 years of age was selected. The sample was divided into 3 groups (Pattern I, II and III) of 20 individuals each. The inclusion criteria for each group were the ANB angle, Wits appraisal and the facial profile angle (G'.Sn.Pg'). To compare the mean values obtained from (SNBa, S-N, S-Ba) each group measures, the ANOVA test and Scheffé's Post-Hoc test were applied. Results and Conclusions: There was no statistically significant difference for the deflection angle of the cranial base among the different facial patterns (Patterns I, II and III). There was no significant difference for the measures of the anterior and posterior cranial base between the facial Patterns I and II. The mean values for S-Ba were lower in facial Pattern III with statistically significant difference. The mean values of S-N in the facial Pattern III were also reduced, but without showing statistically significant difference. This trend of lower values in the cranial base measurements would explain the maxillary deficiency and/or mandibular prognathism features that characterize the facial Pattern III. Keywords: Cranial base. Orthodontics. Maxillofacial development. Face.

Objetivo: o presente estudo avaliou as variações da base craniana anterior (S-N), base craniana posterior (S-Ba), e ângulo de deflexão da base do crânio (SNBa) entre três diferentes padrões faciais (Padrão I, II e III). Métodos: selecionou-se uma amostra de 60 telerradiografias em norma lateral de pacientes brasileiros leucodermas, de ambos os sexos, com idades entre 8 anos e 17 anos. A amostra foi dividida em três grupos (Padrão I, II e III), sendo cada grupo constituído de 20 indivíduos. Os critérios de seleção dos indivíduos para cada grupo basearam-se nos valores de ANB, Wits e ângulo do contorno facial (Gl.Sn.Pg'). Para observar se houve diferença nos valores médios de SNBa, S-N e S-Ba entre os diferentes grupos, utilizou-se a Análise de Variância One Way - ANOVA, seguida de testes post-hoc de Scheffé. Resultados e Conclusões: não houve diferença estatisticamente significativa na deflexão da base do crânio entre os diferentes padrões faciais (Padrão I, II e III). Também não houve diferença significativa nos valores da base anterior e posterior do crânio entre o Padrão I e o Padrão II. Os valores médios de S-Ba apresentaram-se reduzidos no Padrão III, com diferença estatisticamente significativa. Os valores médios de S-N também se apresentaram reduzidos no Padrão III, embora sem diferença estatisticamente significativa. Essa tendência a valores reduzidos da base do crânio poderia explicar a deficiência maxilar e/ou prognatismo mandibular, características que podem estar presentes no Padrão III. Palavras-chave: Base do crânio. Ortodontia. Desenvolvimento maxilofacial. Face.

${ }^{1}$ MSc in Orthodontics and Facial Orthopedics, PUCRS. Professor of Orthodontics, UNISUL and UNIASSELVI.

${ }^{2}$ Specialist in Orthodontics, UNISUL.

${ }^{3}$ MSc in Radiology, UFSC. Professor of Radiology and Stomatology, UNISUL. ${ }^{4}$ MSc in Orthodontics, Bauru School of Dentistry - São Paulo University (FOB-USP). Coordinator of the Specialization Course in Orthodontics, UNIASSELVI. PhD Student in Oral Rehabilitation, FOB-USP.

${ }^{5} \mathrm{MSc}$ and PhD in Orthodontics, FOB-USP. Associate Professor, Department of Orthodontics, São Paulo City University (UNICID). Professor of the MSc Program in Orthodontics, UNICID.

${ }^{6} \mathrm{MSc}$ and $\mathrm{PhD}$ in Orthodontics, FOB-USP. Professor of the Specialization Course in Orthodontics, Dentistry and Health Catarinense Institute.

${ }^{7}$ Head Professor of the Prosthesis Department, FOB-USP. Honorary member of the Ibero Latin American Academy of Craniomandibular Dysfunction and Orofacial Pain.

\author{
How to cite this article: Thiesen G, Pletsch G, Zastrow MD, Valle CVM, Valle- \\ Corotti KM, Patel MP, Conti PCR. Comparative analysis of the anterior and \\ posterior length and deflection angle of the cranial base, in individuals with facial \\ Pattern I, II and III. Dental Press J Orthod. 2013 Jan-Feb; 18(1):69-75. \\ Submitted: September 22, 2009 - Revised and accepted: January 20, 2011 \\ " The author reports no commercial, proprietary or financial interest in the prod- \\ ucts or companies described in this article. \\ Contact address: Guilherme Thiesen \\ Av. Madre Benvenuta, 1285, Santa Mônica \\ CEP: 88.035-001 - Florianópolis / SC - Brazil \\ E-mail: guilherme.thiesen@unisul.br
}




\section{INTRODUCTION}

The cranial base has been the subject of numerous studies. ${ }^{1,4}$ It is a special interest region in orthodontics, once its growth and development are interrelated to the face, directly influencing the growth of the maxilla and mandible and, consequently, the establishment of their anteroposterior relationship.

The cranial base is composed of different bones (sphenoid, ethmoid, frontal, parietal, temporal, and occipital) interconnected by synchondrosis. ${ }^{11}$ It can also be divided into anterior base (S-N) and posterior base (S-Ba or S-Ar). ${ }^{29}$

Initially, during intrauterine life, the cranial base is practically flat. But gradually it suffers deflection, increasing its angulation, due to the growth of the brain. ${ }^{9}$ According to Björk, ${ }^{4}$ the cranial base develops mainly from the chondrocranium, and its shape, during development, may vary considerably. There is a flattening tendency until birth, which changes during the first years of life, gradually flexing until approximately ten years old, when normally its final shape is reached. According to Bishara, ${ }^{3}$ the cranial base reaches $87 \%$ of its adult size at two years of age, $90 \%$ at 5 years and $98 \%$ at 15 years. Also, according to Moore and Lavelle, ${ }^{19}$ the cranial base reaches about $90 \%$ of its total size of about five years of age, and from this age on it can be considered stable. Therefore, its development is fast during the first years of life, followed by a decelerated growth. According to Moyers,${ }^{21}$ the growth of the cranial base is mainly in the anterior-inferior direction, influencing the growth of the maxilla and mandible, being its main growth sites the spheno-occipital, the sphenoethmoidal, the sphenoidal inter-and intraoccipital synchondrosis.

Brodie $^{5}$ emphasized the importance of understanding the growth of the cranial base for orthodontists, since the successful treatment of malocclusions depends, largely, of the entire craniofacial growth. Therefore, orthodontists were gradually understanding that the facial skeleton, in which the teeth and alveolar process are inserted, is closely related with the cranial base, with the nasomaxillary portion connected to its anterior region, and the jaw, to its posterior region. For this reason, any changes that occur between the anterior and posterior cranial base (e.g., changes in the length and angle between them) may generate significant results in the relationships of the facial parts. ${ }^{15}$
Ricketts ${ }^{23}$ stated that the cranial base has an important influence over the total facial prognathism and the establishment of the jaws anteroposterior relationship. Moyers ${ }^{21}$ reported that the growth of the cranial base has a direct effect on the positioning of the mandible and the middle region of the face, and as this base is the most stable of all parts of the craniofacial skeleton, it is less affected by external influences (orthodontic treatment, for example). In 1993, Enlow ${ }^{9}$ mentioned the cranial base as the template over which the face develops. So what happens in the cranial base directly affects the structure, the angles, the size and positioning of the various parts of the face. According to Enlow, ${ }^{9}$ the opening of the cranial base angle causes a retrusive effect on the mandible, and its closure, a protrusive effect.

Therefore, the deflection angle and the size of the cranial base have been considered as potential causes of skeletal Class II malocclusions, where an increased length of the anterior cranial base would be associated with an anterior displacement of the maxilla ${ }^{24}$ and a increased cranial base angle would be correlated with a higher degree of mandibular retrusion. However, when Ngan, Byczek and Scheick ${ }^{22}$ and Varella ${ }^{28}$ studied the early morphological characteristics of the Class II malocclusion, they found a normal configuration and bending of the cranial base.

Guyer et $\mathrm{al}^{13}$ compared cephalometric radiographs of Class III patients with Class I patients. They found a shorter posterior cranial base in subjects with Class III, and no significant difference for the angle of the cranial base. On the other hand, Marquez ${ }^{18}$ using cephalometric radiographs of 30 patients with mandibular prognathism and comparing them with a control group, observed that the anterior portion and the deflection angle of the cranial base are smaller in Class III patients. Sanborn ${ }^{25}$ compared 42 Class III subjects with a control group (35 individuals), and observed a lower S-N value in the Class III group. The author also found statistically significant correlation between the slope of cranial base and the Class I, II and III malocclusions, being that the $\mathrm{SNBa}$ angle is sharper in Class III malocclusion.

Mouakeh, ${ }^{20}$ when analyzing the morphological characteristics of the craniofacial complex in children with Class III malocclusion, reported that the anterior and posterior cranial base were significantly lower than the control group. However, in a retrospective cephalometric study performed by Dhopatkar et al. ${ }^{8}$ the results 
showed that the deflection of cranial base have no fundamental importance in determining the malocclusion, since the mandibular size was significantly different in the different malocclusions.

According to Moyers, ${ }^{21}$ a pattern is a set of restraining rules acting to preserve the integration of the parts under various conditions. In this way, it was suggested that the face morphogenetic patterns and the maxillomandibular growth should be considered with the same connotation. In 1907, Angle ${ }^{2}$ said that the orthodontist would be able to classify malocclusion by facial evaluation only. According to Capelozza Filho, ${ }^{6}$ a facial pattern is the "management of facial configuration throughout time", and once the facial morphology is defined, the individual is diagnosed as having particular facial pattern with all its relevant features, therefore allowing the understanding of the malocclusion and its prognosis. One must understand that the study of some variables is not enough to determine the morphological facial pattern of the individual. However, these may be aggregated to the characteristics pertinent to a specific facial pattern. Therefore, the objective of this study was to compare the angular (SNBa) and linear ( $\mathrm{S}-\mathrm{N}$ and $\mathrm{S}-\mathrm{Ba})$ measurements of the cranial base in subjects with different facial patterns (Pattern I, II and III).

\section{MATERIAL AND METHODS}

For this study, sixty cephalometric radiographs from Brazilian individuals aged between 8 and 17 years, of both genders, were selected., All subjects were or have been under orthodontic treatment at the Clinic of Orthodontics, University of Southern Santa Catarina - UNISUL. The sample was subdivided into three groups (Pattern I group; Pattern II group and Pattern III group), each group being composed of twenty (20) cephalometric radiographs.

The selection criterion for the age group ranging from 8 to 17 years of age was based on the age at which the cranial base has already reached the growth peak and also its final morphology. From this age on it continues to grow, but in reduced proportions and without changing its configuration. On the other hand, during this same period, the different facial patterns characteristics are developed and confirmed. The sample's mean age was 12 years and 4 months, and for each group as follows.
» Pattern $\mathrm{I}-12$ years and 10 months.

" Pattern II - 13 years and 1 month.

" Pattern III - 11 years and 2 months.

The lateral cephalometric radiographs, part of the initial orthodontic records of each individual, were previously obtained at the same radiological service, pertaining

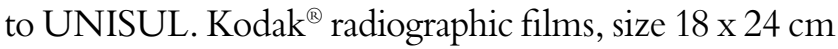
were used. The radiographs were processed by the radiological service using an Imaging Corp ${ }^{\circledR}$ (All-Pro), model All-Pro in a proper darkroom, using a total processing time of 2 minutes. No correction was performed for the linear magnification of the radiographic images (approximately $7 \%$ compared to the median plane). All cephalometric tracings were manually performed by the same previously calibrated investigator, using black pencil $0.3 \mathrm{~mm} \mathrm{HB}$. The comparative analysis between groups was performed by means of angular and linear measurements obtained from the cephalometric radiographs, with scale of 0.50 degrees and $0.5 \mathrm{~mm}$. These measurements allowed the assessment of the cranial base morphology and also its relations with the maxilla and the mandible. The cephalometric points, planes and angles used in this study were the following:

" S (sella): Situated at the midsagittal region of the sphenoid bone center. The point should be marked at the sella turcica's geometric center.

" $\mathrm{Ba}$ (basion): Located at the most inferior point on the anterior margin of the foramen magnum, in the sagittal plane.

" $\mathrm{N}$ (nasion): Located in the most anterior region of the frontonasal suture (suture between the frontal and nasal bone).

"A-point (subspinale): Located in deepest region of the premaxilla's anterior curvature.

" B-point (supramentale): Located at the deepest point of the anterior curvature of the alveolar process of the mandible.

" G' (soft tissue glabella): Located at the soft tissue glabella.

"Sn (subnasale).

" Pg' (soft tissue pogonion).

" $\mathrm{S}-\mathrm{Ba}$ (posterior cranial base).

" $\mathrm{S}-\mathrm{N}$ (anterior cranial base).

" SNBa: Expresses the degree of deflection of the cranial base.

"ANB: Expresses the maxillomandibular relation to the cranial base. 
" G'.Sn.Pg' (angle of facial convexity): Expresses the maxilla-mandibular anteroposterior relationship in soft tissue profile.

"Wits: Expresses linearly, the anteroposterior relationship between the maxilla and the mandible.

The Figure 1 shows a standard cephalogram used in this study.

For examiner calibration, twenty radiographs of the sample were selected masked (to avoid any biased analysis) and analyzed for a second time, respecting a 10 days interval. From these measurements, the Kappa test was applied. To calculate the random error, Dahlberg's formula was used.

To determine the inclusion of individuals in their respective group each facial pattern characteristics (Pattern I, II or III) was taken into account, as recommended by Capelozza Filho ${ }^{6}$ as well as the facial convexity angle (G'.Sn.Pg') according to Suguino et al. ${ }^{27}$ In addition, each individual's ANB angle and Wits appraisal were analyzed. The mean values for ANB, Wits and G'.Sn.Pg' of each group were as follows (Table 1):

"Pattern I group: $\mathrm{ANB}=3.25^{\circ}$, Wits $=0.82 \mathrm{~mm}$ and G'.Sn.Pg' $=166.8^{\circ}$.

" Pattern II group: $\mathrm{ANB}=8.53^{\circ}$, Wits $=5.26 \mathrm{~mm}$ and G'.Sn.Pg' $=158.27^{\circ}$.

" Pattern III group: ANB $=-1.5^{\circ}$, Wits $=-6.2 \mathrm{~mm}$ and G'.Sn.Pg' $=174 \cdot 3^{\circ}$.

Once the groups were delimited, the measurements of the cranial base (SNBa, S-N and S-Ba) were assessed for the whole sample. The study data were then presented as mean and standard deviation for the three groups. To assess if there was difference in the SNBa, S-N and $\mathrm{S}-\mathrm{Ba}$ analyses between different facial patterns, we used the one-way analysis of variance (ANOVA) followed by Scheffé post-hoc tests.

\section{RESULTS}

From the analysis, Kappa test and percent agreement were applied (Table 2), observing that the examiner was able to conduct all analyses of this research. For the random error, no significant value was found for representative of error for angular and linear measurements, with the greatest measurement difference found being of $0.5^{\circ}$ and $0.5 \mathrm{~mm}$, respectively.

The mean value found for the cranial base deflection angle (SNBa) for Pattern I individuals was $131.7^{\circ}$, with a

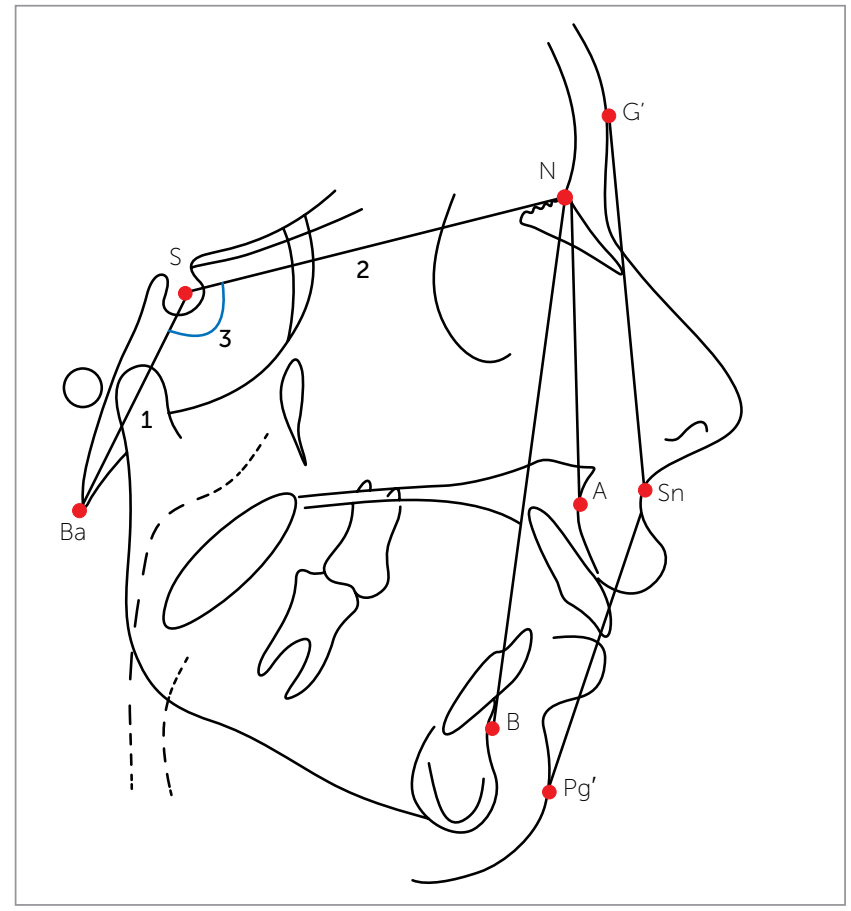

Figure 1 - Standard cephalogram used in the study. 1) posterior cranial base: 2) anterior cranial base; 3) cranial base angle.

standard deviation of $4.5^{\circ}$. In Pattern II group, the average value of $\mathrm{SNB}$ a was $132.8^{\circ}$, with a standard deviation of $4.9^{\circ}$. For Pattern III group, the average value of SNBa was $132.5^{\circ}$, with a standard deviation of $3.2^{\circ}$. There was no statistically significant difference for the SNBa value in the different facial patterns assessed, using the oneway analysis of variance (ANOVA) (Table 2).

In the evaluation of the anterior cranial base (S-N, the mean value found for Pattern I group was $69.4 \mathrm{~mm}$, with a standard deviation of $2.3 \mathrm{~mm}$. In Pattern II group, the mean value of S-N was slightly higher, presenting with $70.4 \mathrm{~mm}$ and a standard deviation of $4.7 \mathrm{~mm}$. Although there was no statistically significant difference, the Pattern III group had the lowest mean value for the anterior cranial base, which was $67.1 \mathrm{~mm}(\mathrm{SD}=4.1 \mathrm{~mm})$ (Table 3).

The posterior cranial base (S-Ba) mean value for Pattern I group was $46.0 \mathrm{~mm}$, with a standard deviation of $2.7 \mathrm{~mm}$. For the Pattern II group, showed a $46.8 \mathrm{~mm}$ mean, with a standard deviation of $2.9 \mathrm{~mm}$. In Pattern III group the mean value was once again reduced and showed statistically significant difference, being $42.5 \mathrm{~mm}$, with a standard deviation of $3.0 \mathrm{~mm}$ (Table 3). 
Table 1 - Mean values for ANB, Wits and G'.Sn.Pg' for the three studied facial patterns.

\begin{tabular}{llll}
\hline Group & Pattern I & Pattern II & Pattern III \\
ANB & $3.25^{\circ}$ & $8.53^{\circ}$ & $-1.5^{\circ}$ \\
Wits & $0.82 \mathrm{~mm}$ & $5.26 \mathrm{~mm}$ & $-6.2 \mathrm{~mm}$ \\
\hline G'Sn.Pg' $^{\prime}$ & $166.8^{\circ}$ & $158.27^{\circ}$ & $174.3^{\circ}$ \\
\hline
\end{tabular}

Table 2 - Kappa test and percentage agreement values for intraexaminer calibration.

\begin{tabular}{lccc}
\hline Analysis & Kappa Values & $\mathbf{P}$ & $\begin{array}{c}\text { Percent } \\
\text { agreement }\end{array}$ \\
\hline SNBa & 1.000 & $<0.0001^{*}$ & $100 \%$ \\
\hline G'Sn.Pg' & 0.928 & $<0.0001^{*}$ & $95 \%$ \\
\hline S-Ba & 0.935 & $<0.0001^{*}$ & $95 \%$ \\
S-N & 1.000 & $<0.0001^{*}$ & $100 \%$ \\
Wits & 1.000 & $<0.0001^{*}$ & $100 \%$ \\
ANB & 1.000 & $<0.0001^{*}$ & $100 \%$ \\
\hline
\end{tabular}

* Statistically significant.

After performing the ANOVA test, it was found statistically significant difference between of the groups only for the posterior cranial base (S-Ba) mean values (Table 4). Post-hoc Scheffé tests were conducted to locate the significant differences between the different patterns. Differences were detected to the value of S-Ba between Pattern III and Pattern I groups $(\mathrm{P}=0.007)$, and between Pattern III and Pattern II groups $(\mathrm{P}=0.001)$.

\section{DISCUSSION}

The human skull, especially its base, has always aroused the interest of many scientists, such as anthropologists and orthodontists. Current orthodontics is no longer restricted to dental arches and their occlusion. Its constant evolution has enabled a better understanding of the craniofacial growth and development, thus obtaining an integrated view of the cranium, face, TMJ and dental occlusion.

Coben $^{7}$ analyzing the integration of the craniofacial skeleton variants, emphasized that, when evaluating individual craniofacial skeletal patterns, a greater perspective on the etiology of malocclusions is found. This is because not all Class II and III malocclusions can be explained based on the mandibular and/or maxillary size. When considering the relationship of the cranial base with the dentofacial complex, one concludes that the factors combination is complex, with a great array of adjustments, and the integration of these factors determines the facial harmony or disharmony.
Table 3 - Mean and standard deviation values for the different measurements performed in the three studied facial patterns.

\begin{tabular}{llll}
\hline Group & Pattern I & Pattern II & Pattern III \\
SNBa & $131.7 \pm 4.5$ & $132.8 \pm 4.9$ & $132.5 \pm 3.2$ \\
S-Ba & $46.0 \pm 2.7$ & $46.8 \pm 2.9$ & $42.5 \pm 3.0$ \\
S-N & $69.4 \pm 2.3$ & $70.4 \pm 4.7$ & $67.1 \pm 4.1$ \\
\hline
\end{tabular}

Table 4 - ANOVA (F) results and respective significance probability performed for the different facial patterns.

\begin{tabular}{lcc}
\hline Analysis & Test result (F) & P \\
SNBa & 0.257 & 0.774 \\
S-Ba & 9.626 & $<0.0001^{*}$ \\
S-N & 2.828 & 0.070 \\
\hline
\end{tabular}

* Statistically significant.

In this study, the size of the posterior cranial base, in Pattern III, showed a statistically significant difference (reduced when compared to Pattern I and II). This may help explain the prognathism that occurs in this facial type. A reduced posterior cranial base generates a more anterior position of the glenoid fossa of the temporal bone, where the mandibular condyles are articulated with the cranial base. ${ }^{9}$ Being this joint in a more anterior position, the ramus and, consequently, the entire jaw, will also be more anteriorly positioned, leading to mandibular prognathism. ${ }^{4}$ Enlow, ${ }^{9}$ in one of his papers on the relationship between the cranial base and the jaws, states that individuals with a cranial base of reduced size have a tendency to a more brachycephalic head shape. As a result on the face, it is found a relatively retrusive nasomaxillary complex and a more anterior positioned jaw, resulting in a greater tendency for a prognathic profile. However, Enlow ${ }^{9}$ himself states that most individuals presents structural characteristics that compensate these morphogenetic trends of facial pattern (in this case, a smaller jaw or a larger maxilla, for example). Thus, these features can compensate in a greater or lesser degree, a structural disharmony presents in cranial base, where the individual can present at least reasonable facial proportions. However, if these compensatory characteristics do not occur, or if it is insufficient, the cranial base intrinsic morphogenetic tendencies will be expressed with great severity and gravity on the face of the individual. 
In this study, Pattern III also presented difference when compared to Pattern I and II, for the mean values of the anterior cranial base length. Although there was no statistically significant difference, this value was reduced in Pattern III group. This result, like the reduced posterior base, can help explain the concave facial profile in Pattern III. This is because the nasomaxillary complex develops over this region., 5,9,21 Thus, a reduced length of anterior cranial base can result a retrusive positioning of the whole nasomaxillary complex. In the facial profile, this is expressed as a tendency to poor middle-third of the face. Björk, ${ }^{4}$ when studying the human prognathism, stated that a shortening of the anterior cranial base is accompanied by an increase of facial prognathism if the other structures involved remain unchanged. This is consistent with the results of this study. However, the shortening of the cranial base is not the prime factor for a facial Pattern III, since it can present other important etiologic factors. Nevertheless this shortening is usually present in Pattern III, contributing in a greater or lesser degree, to the characteristic profile of this group.

According to Weidenreich, ${ }^{30}$ a sharper SNBa angle is usually related to a more brachycephalic skull and greater mandibular prognathism. Enlow ${ }^{9}$ found a sharper SNBa angle, a short middle-third of the face and mandibular ramus with a more anterior orientation in subjects with Angle's Class III malocclusion, when compared to a control group. The same authors found, in subjects with Class II malocclusion, a less sharp SNBa angle, with a base of greater length when compared to a control group (Class I).

According to Björk, ${ }^{4}$ a reduced $\mathrm{SNBa}$ angle and shortening of the cranial base, would some of the facial prognathism causes. He also asserts that the opposite is true, where an increase in the angle of the cranial base, as well as a greater length base, would be responsible for a more retrognathic facial pattern. However, the difference between the anteroposterior positioning of the maxilla and mandible is partly due to variation in the size of the jaws, and partly due to variation in the length and flexure angle of the cranial base, which are associated with the both jaws.

The angle of the cranial base (SNBa) did not differ between the different groups. This result is consistent with what Freitas ${ }^{12}$ found on his studies. There were also no statistically significant differences between the linear dimensions of the cranial base (S-N and S-Ba) between Pattern I and Pattern II. But these results do not confirm what part of the literature describes about the subject. . $^{1,8,8,9,12,15}$

This study investigated the differences in the deflection angle of the cranial base, as well as in the length of its anterior $(\mathrm{S}-\mathrm{N})$ and posterior $(\mathrm{S}-\mathrm{Ba})$ portions in different facial patterns (Pattern I, II and III). However, it is important to keep in mind that the morphogenetic facial pattern is formed by a series of specific characteristics of each face type. And each of these characteristics alone does not define a facial pattern. It also possible to have compensations in maxillomandibular structures. These compensations can act minimizing an abnormal morphological pattern of the cranial base.

The fact that these values (SNBa for the three groups and S-N and S-Ba for Pattern I and II) did not show significant differences can be explained by such morphological compensation existing in the studied subjects. For example, when comparing Pattern I and II individuals, they can present values for SNBa, S-N and S-Ba, within the normal range. The difference in these facial patterns may have been caused by a smaller mandible and / or a larger maxilla in the Pattern II individual.

Therefore, it would be interesting to conduct further studies on the topic, including larger specificities between different facial patterns (separating the Pattern III caused by maxillary deficiency from the Pattern III caused by mandibular excess; separating the Pattern II caused by maxillary excess from the Pattern II caused by mandibular deficiency, for example), thus distinguishing the main etiological factor for each facial pattern.

Current orthodontics does not accept absolute normal values anymore. Facial harmony is expressed by a combination of floating norms of the angles and proportions, especially in a population with high racial miscegenation as the Brazilian population. Each person has a unique facial architecture. Therefore, the study of one variable, alone, is not sufficient to understand the characteristics of a facial type. However, the orthodontist should not forget that in some cases the causative morphological factor of a disharmonic facial pattern, such as Patterns II and III, can also result from alterations present in the cranial base, and not only from a linear disproportion between the structures of the jaws. This "missing link" often ends up being neglected by the professionals in the patients' 
craniofacial evaluation. We must know the role of each variable within a whole, and thus successfully diagnose the main etiology of a certain disease.

\section{CONCLUSIONS}

In the studied sample, there was no difference between the mean values for the deflection angle of the cranial base (SNBa) in different facial patterns (I, II, III).
There was statistically significant difference for the mean values of the posterior cranial base $(\mathrm{S}-\mathrm{Ba})$ for the Pattern III group. In this group, the posterior cranial base was reduced when compared with Pattern I and II groups.

Although without statistical difference, the anterior cranial base $(\mathrm{S}-\mathrm{N})$ in the Pattern III group was reduced when compared to Pattern I and II.

\section{REFERENCES}

1. Anderson D, Popovich F. Relation of cranial base flexure to cranial form and mandibular position. Am J Phys Anthropol. 1983;61(2):181-7.

2. Angle EH. Treatment of malocclusion of the teeth. Philadelphia: The S. S. With Dental Manufacturing: 1907.

3. Bishara SE. Ortodontia. São Paulo: Ed. Santos; 2004.

4. Björk A. Cranial base development. Am J Orthod. 1955;41(3):198-225.

5. Brodie AG Jr. The behavior of the cranial base and its components as revealed by serial cephalometric reontgenograms. Angle Orthod. 1955;25(3):148-160.

6. Capelozza Filho L. Diagnóstico em Ortodontia. Maringá: Dental Press; 2004.

7. Coben SE. The integration of facial skeletal variants. Am J Othod. 1955:41(6):407-34

8. Dhopatkar A, Bhatia S, Rock P. An investigation into the relationship between the cranial base angle and malocclusion. Angle Orthod. 2002;72(5):456-63.

9. Enlow DH. Crescimento facial. 3a ed. São Paulo: Artes Médicas; 1993

10. Faltin Jr. K. A individualização do diagnóstico e conseqüentes opções de tratamento. In: Grupo brasileiro de Professores de Ortodontia e Odontopediatria. São Paulo; 1997. p. 166-72.

11. Ferner AG, Staubesand RT. Sobotta Atlas de Anatomia Humana. Rio de Janeiro Guanabara Koogan; 1983.

12. Freitas JC. Influência da base craniana nas más oclusões [dissertação]. Rio de Janeiro (RJ): Universidade Federal do Rio de Janeiro; 1983.

13. Guyer EC, Ellis EE 3rd, MCNamara JA Jr, Behrents RG. Components of Class III maloclusion in juveniles and adolescents. Angle Orthod. 1986;56(1):7-30

14. Jacobson A, Evans WG, Preston CB, Sadowsky PL. Mandibular prognathism. Am J Orthod. 1974; 66(2):140-71

15. Kasai K, Moro T, Kanazawa E, Iwasawa T. Relationship between cranial base and maxilofacial morphology. Eur J Orthod. 1995:17(5):403-10.

16. Klocke A, Nanda RS, Kahl-Nieke B. Skeletal Class II paterns in the primary dentition. Am J Orthod Dentofacial Orthop. 2002:121(6):596-601

17. Lanza P, Santos Pinto A, Bolini PDA. Estudo cefalométrico do crescimento e flexão da base do crânio humano do nascimento aos seis meses de idade. Rev Dental Press Ortod Ortop Facial. 2003:7(2):33-9.
18. Marquez IM. Avaliação do padrão facial, preparo ortodôntico e capacidade do tratamento cirúrgico em pacientes Classe III com prognatismo mandibular [tese]. Bauru (SP): Faculdade de Odontologia de Bauru; 1993.

19. Moore WJ, Lavelle CLB. Growth of the facial skeleton in the hominoidea. New York: Academic; 1974

20. Mouakeh M. Cephalometric evaluation of craniofacial pattern of Syrian children with Class III maloclusion. Am J Orthod Dentofacial Orthop. 2001;119(6):640-9.

21. Moyers RE. Ortodontia. 4aㅡ ed. Rio de Janeiro: Guanabara Koogan; 1991.

22. Ngan PW, Byczek E, Scheick J. Longitudinal evaluation of growth changes in Class II division 1 subjects. Semin Orthod. 1997;3(4):222-31.

23. Ricketts RM. Planning treatment on the basis of the facial pattern and an estimative os its growth. Angle Orthod. 1957:27(1):14-37.

24. Rothstein T, Yoon-Tarlie C. Dental and facial skeletal characteristics and growth of males and females with Class II, division 1 malocclusion between the ages of 10 and 14 (revisited) - Part I: characteristics of size, form, and position. Am J Orthod Dentofacial Orthop. 2000;117(3):320-32

25. Sandborn RT. Differences between the facial skeletal patterns of Class III malocclusion and normal occlusion. Angle Orthod. 1955;25(4):208-22.

26. Scott JH. Dentofacial development and growth. Oxford: Pergamon; 1967.

27. Suguino R, Ramos AL, Terada HH, Furquim LZ, Maeda L, Silva OG Filho. Análise Facial. Rev Dental Press Ortod Ortop Maxilar. 1996;1(1):86-107.

28. Varrela J. Early developmental traits in Class II malocclusion. Acta Odontol Scand. 1998:56(6):375-7.

29. Vion PE. Anatomia cefalométrica. São Paulo: Ed. Santos; 1994

30. Weidenreich F. Some particulars of skull and brain of early hominids and their bearing on the problem of the relationship between man and anthropoids. Am J Phys Anthropol. 1947:5(4):387-427. 